\title{
Lithuania in the Context of NATO Enlargement
}

\begin{abstract}
This article is aimed to provide an analysis of the circumstances and problems related to Lithuania's integration into NATO. It presents an overview of the path of EuroAtlantic integration Lithuania has taken as well as the reasons behind the favourable outcome of NATO's Prague Summit in November 2002, discusses factors which have had an impact on NATO enlargement and their interplay: a general development of the geopolitical landscape in Europe and Lithuania's efforts to receive an invitation of membership. The context of NATO enlargement is used to review Lithuania's security policy, relations with Russia, as well as the influence of Russia as a specific and exclusive factor in the processes of NATO enlargement. The article concludes with a summary of Lithuania's foreign policy objectives and priorities for the post-Prague period.
\end{abstract}

\section{The Prague Summit and Lithuania}

The outcome of the NATO Prague Summit and the significance of the invitation to Lithuania to join the North Atlantic Treaty Organisation in particular will be fully appreciated, apprehended and analysed only after some time, but already today, in the mood of elated emotions, we can make first generalisations. The invitation means a conclusive consolidation of Lithuania's independence. The invitation testifies that Lithuania has firmly anchored in the community of Western states as part of a united and free Europe and no longer is a hostage to the changing Eastern-Western winds. We are abandoning the concept of "immediate abroad" for good and are acquiring new, greater and real possibilities of developing friendly equitable relations with neighbouring countries. The invitation means a totally new quality of security and stability for Lithuania that will allow us to focus our attention and efforts on a more rapid solution of economic, social, ecological and other issues.

The invitation also means work. Hard and demanding work to secure Lithuania's presence in the West. Work within a new family by the rules of the new family. If we are part of the new system, the invitation also means responsibility not only for ourselves, but also for the future of Europe as a whole.

"Giedrius Čekuolis - Undersecretary of the Ministry of Foreign Affairs of the Republic of Lithuania, Chief coordinator of Lithuania's integration into NATO. Address: J. Tumo-Vaižganto 2, LT2600 Vilnius, Lithuania, tel. +370-5-2362412, e-mail: giedrius.cekuolis@urm.lt 


\section{Shaking off the "special case" label: Lithuania's path of Euro-Atlantic integration before the Prague Summit}

Looking back at the path of Lithuania's integration into NATO until the Prague Summit, I would dare say that the largest achievement over the past twelve years is that Lithuania and the other Baltic States in the area of geopolitical security have not become the so-called "special case". And there was a real threat this might have happened. The majority of politicians, diplomats and political scientists in Europe and the USA used to say that the Baltic States' membership of NATO may destabilise security in the Baltic region and Europe. Attention was drawn to the particular sensitivity of Russia to this issue since for fifty years Lithuania, Latvia and Estonia were incorporated into the USSR (regardless of the fact that this was done illegally!). Hence, our natural strive for the same type of security (based on NATO and the EU) enjoyed by other new democracies in Europe might have troubled the unpredictable Russia. Lithuanian diplomats were consistently fighting against this "special case" label, because there was simply no other alternative. In his address to the NATO Parliamentary Assembly session in Vilnius on 29 May 2001, Lithuania's Foreign Affairs Minister Antanas Valionis said: “As regards discussions on "special case", we do agree that Vilnius is indeed "special" and that we have a soft spot for basketball. But, frankly speaking, here in Lithuania we are sick of this "special case" labelling in the context of NATO enlargement. Are we (i.e. the Baltic States - G.Č.) a "special case" all because we follow the same fundamental political principles, i.e. the rule of law, respect for human rights and freedoms, a democratic political set-up, political pluralism, civic society and market economy? $<\ldots .>$ Let's be frank. The only "special" item here is that there exists an anachronistic fear that inviting the Baltic States to join NATO could trespass the mythical red line. We, however, look at it from another perspective: the invitation of the Baltic States would constitute a historical victory of justice, and would rightly place the three Baltic nations, whose destinies bear a tragic imprint of the Molotov-Ribbentrop Pact followed by Soviet occupation and Yalta, in European matters."

How did we win then and were not turned into "a grey zone" - "a special case" of Europe? I believe the key to our success was our ability to prove to NATO members over twelve years of independence that Lithuania as well as Latvia and Estonia are predictable states. A predictable behaviour always earns the trust of partners and the sense of security in cooperation. We proved that our Western orientation is our ultimate destination, that never again we will emerge somewhere in the expanse of the CIS. A perfect illustration of our consistency is the fact that during 12 years of independence we have had almost eleven cabinets of "every hue", and, nonetheless, have not changed Lithuania's foreign policy directions and priorities.

The time factor is also highly important. Indeed, time was needed to build up a political and economic context as well as to change stereotypes of thinking of our Western partners. Several years ago, an ambassador of a small NATO member state told me: "Do you know what is your (i.e. the Baltic States' - G. C..) major problem? The problem is that for the most of Europeans a journey to Lithuania, Latvia and Estonia is still an adventure"... My colleague was right. I recall perfectly well how visiting foreign guests during the first Conference "Vilnius Nine" in May 2000 or 
even during the 2001 May NATO Parliamentary Assembly session in Vilnius were sincerely amazed by a "discovery" that mobile communications worked in Vilnius! In addition, Vilnius is a city of good restaurants and cafes; Lithuania is a home country of delicious beer! This only illustrates a phenomenon of general unawareness or of very low awareness - over 50 years of Soviet occupation we have been simply forgotten. Concern for new candidates was felt during Lithuania's integration into Euro-Atlantic structures too - who are these Lithuanians, what type of foreign policy will they follow, won't the Balts become some sort of "Che Guevarras", will they be capable of building up a solid, peaceful and responsible foreign policy towards its neighbours. Time was needed to answer these questions and to answer them by work rather than declarations. The Prague Summit has demonstrated that we have succeeded in that. We have proven. We have convinced. After all, those 12 years may seem not such a long period, particularly in light of the post-Prague heights. Although I remain convinced that the famous phrase of the said ambassador that "going to the Baltics is still an adventure" remains a challenge for us in the future.

A positive development of the Lithuanian-Russian relations and the constructive policy of Vilnius towards Moscow has been of great significance for Lithuania's aspirations to Euro-Atlantic integration. A streamlined withdrawal of the Soviet army from Lithuania, the concluded inter-state treaties, development of trade, tens of initiatives and cooperation projects, "internationalisation" of the issue of Kaliningrad, drawing of the European Union's attention have all ensued manifold political dividends for Lithuania in the eyes of NATO members. To my mind, we may fairly reasonably state that among the Baltic States Lithuania has played a role of a driving force in persuading NATO member states that we know how to talk with Russia and that we use a civilised and Western-type terminology. During a dinner in the spring of 2002, a defence minister of a large NATO member state admitted to me that NATO's concern was that after joining NATO the Balts might stick out their tongue at Russia... Now we have already proven that we embrace a double responsibility - both as future NATO members and as eternal neighbours of Russia, that good relations with Russia was our aim rather than a political show. Indeed, Russia is progressing more slowly, remains highly unpredictable, is burdened with post-imperialistic complexes, and yet this very background has helped to manifest even more clearly Lithuania's constructive and pragmatic policy. Later in this article I will come back to the analysis of Lithuania's security policy in the context of its relationship with Russia.

Of considerable importance for Lithuania's integration into NATO and the process of enlargement as a whole were the terrorist attacks of 11 September 2001. Firstly, there was some sort of confusion and a non-escalated concern among a few NATO aspirants - whether, in light of new threats and challenges of the $21^{\text {st }}$ century, NATO enlargement was to survive as a priority of the USA administration and governments of other NATO member states? Right from the start, Lithuania demonstrated its political solidarity and practical contribution to fight against terrorism. The USA positively assessed a clear stand of Lithuania within the anti-terrorist coalition, resolute statements of Lithuania's political leaders, a rapid favourable response from the USA requesting the issue of a long-term diplomatic authorisation for flights over the airspace of the Republic of Lithuania, participation of Lithuanian military doctors and other forces in concrete actions of the coalition. In his letter of 26 September 2001 to the President of Lithuania Valdas Adamkus, President George W. Bush said 
that the best preparation for NATO membership was exactly what Lithuania was doing already, namely, acting as an (NATO) ally. Today we may state that the terrorist attacks in the USA had a boomerang effect but not the one the authors of these attacks might have attempted for: they have consolidated and accelerated the process of NATO enlargement in political terms, have put the conditions in place favourable for an extensive NATO-Russia cooperation, which, in its turn, has helped Lithuania and the other Baltic States shake off the "special case" label faster.

\section{The process of NATO enlargement: factors and their interplay}

The decision on NATO enlargement has always been political, i.e. enlargement is impossible without a clearly stated wish by NATO members to enlarge. However, the process of enlargement itself is composed of many components and factors: it entails the political will of NATO to expand, general global geopolitical developments, Western orientations of the values of aspiring countries, development of the V-10 process, home policy reforms, economic development, amplification of armed forces and development plans, Membership Action Plans and Partnership for Peace Programmes, our administrative capacities, the level of corruption, etc. In short, this is a whole package of issues. The development of some of them was beyond the aspirants' will, but affected the enlargement process; others made the aspirants search for solutions, i.e. do the so-called "homework". A decent homework could not yet guarantee an automatic acceptance to the Alliance, though it was closely related to NATO's political will to enlarge, and vice versa.

As regards countries of Western Europe, it should be noted that NATO enlargement is not only about an altruistic deed. It is also about the expanding the zone of peace and stability, recognising the values of the Western civilisation. At the same time, the zone of the Western influence has also expanded. NATO is getting stronger, and the security of its individual members - both current and new - is enhanced. A process of consolidating a united, safe and free Europe under the flags of Western democracies has been brought to an end. NATO Secretary General Lord Robertson talked about the necessity for the Alliance's enlargement during the Chicago Council on Foreign Relations: "First, NATO enlargement is not about accumulating military capabilities against "the other side". There is no "other side" at the moment. The context of NATO enlargement today is about community-building: about overcoming the divisions that still exist in Europe. It is about improving the security and the stability of Europe as a whole. Europe can never be truly stable if there are divisions between a prosperous, self-confident West and a less prosperous, less confident East. One half of Europe simply cannot be kept at arm's length forever. And let me be very clear: this applies to every democratic country in Europe. In the new Europe of the $21^{\text {st }}$ century, geography can no longer be destiny". ${ }^{1}$ The distinguished political scien-

${ }^{1}$ Lord Robertson, "NATO's Challenges: Illusions and Realities" Chicago Council on Foreign Relations, 19.06.2001. 
tist Zbigniew Brzezinski, when speaking at the Vilnius Group premiers' meeting in Bratislava on 11 May 2001, underlined that: "NATO enlargement may not be valued only in terms of military benefit, although it is clear that each Ally has to make a contribution to the common security. By itself, NATO enlargement reinforces common security in Europe since it eliminates geo-politically ambiguous regions". During the NATO Heads of State Meeting in the USA on 23-24 April 1999, the famous Washington Declaration was made, wherein the states of the Alliance confirmed that they would continue NATO's "open-door policy" also following the first wave of enlargement: "Our Alliance remains open to all European democracies, regardless of geography, willing and able to meet the responsibilities of membership, and whose inclusion would enhance overall security and stability in Europe."

Hence, we witness an obvious political will of the Alliance to enlarge. However, despite official commitments by NATO members to follow the "open-door" policy, it could be felt that the enthusiasm over enlargement right after the Washington Summit faded. There were a number of reasons for that: the first wave of enlargement just being over, there was a wish to wait, not to rush, and to see how the new entrants would make it. Several NATO member states in Europe already felt having fulfilled their objectives of the reinforcement of security, while the candidates for the second wave did not seem to be highly appealing - their armed forces were either modest or large but in a catastrophic state - a true Soviet-type legacy. A tribute was then paid to the Balkan crisis. The Baltic States were trying hard to shake off the "special case" labels and were setting themselves free from other stereotypes brought about by the above-mentioned "time factor". Today, looking in retrospect, the process of enlargement from the summer of 1999 to the summer of 2001 seems logical and even sufficiently dynamic, back then, however, a certain degree of anxiety and non-clarity was being felt. Aspirants were thinking hard how to keep the issue of the Alliance's enlargement as a top priority in NATO capitals, while NATO members were occupied with contemplating how to safeguard the reliability of NATO's "opendoor" policy and consolidate it with some sort of flesh. This is how the V-9, in the beginning as the Vilnius Nine and later as the Vilnius Ten after Croatia's joining, came into existence as a policy of political solidarity and cooperation of NATO aspirants, this is how Membership Action Plans for these aspirant countries were developed, i.e. concrete homework that each candidate committed to do and which we are going to talk about later.

I would dare say that at the start in many NATO capitals the V-10 process was met with scepticism. Journalists named it as a big bang scenario of NATO's enlargement. In diplomatic circles, concerns were being expressed that such type of enlargement might trigger unnecessary tensions, deteriorate relations with Russia. At the beginning, the enthusiasm of the Vilnius Ten members was far from being unanimous. In a way, everyone was "for it", however, the minds of some high-level politicians of V-10 countries were harbouring the notion of "sneaking in by one at a time". Others voiced complaints, such as what do we need these Balts for; they would be nothing but a millstone round our neck... And yet the first Vilnius Conference in May 2000 proved to be a success. Aspirants demonstrated their ability to work toget-

\footnotetext{
${ }^{2}$ The Washington Declaration, April 23, 1999.
} 
her in a team. The Vilnius Declaration clearly formulated the following aims of the V-10: building a united, indivisible and free Europe, NATO - a guarantee of security and stability in Europe and America. The Vilnius Declaration concluded with a call to the Alliance's heads of state to deliver on their promise made during the Washington Summit the creation of a united and free Europe. On the occasion of the Vilnius Conference, President Valdas Adamkus received a letter from the USA President George W. Bush in which he underlined his support to the leaders who gathered then in Vilnius to discuss the role of NATO in the future Europe. "USA security is inseparable from security in Europe, while strong NATO is a basis for security", the letter read. NATO Secretary General Lord Robertson made a speech at the Vilnius Conference that received a wide coverage in foreign press. Even as a first try, it was quite a successful one, which largely determined the further course of the Vilnius process. The key events to be mentioned are: the V-10 premiers' meeting in May 2001 in Bratislava, V-10 foreign ministerial meeting in June 2001 in Tallinn, in October 2001 - in Slovenia, in December 2002 - premiers' meeting in Bucharest, in July 2002 - premiers' meeting in Riga. We can maintain very firmly that the Vilnius Ten made a substantial contribution to the processes of NATO enlargement, helped to maintain the discussion on enlargement issues in NATO capitals. In cooperation with the $\mathrm{V}-10$, the process did not become anything else but an affirmation and manifestation of political solidarity and team-working capacity of the aspirants. The basis for appraising each aspirant became individual "homework" appraising each aspirant's efforts.

In the context of NATO enlargement, the position of the USA as the leader of the process was a major driving force both during the first and the second waves of enlargement. The address by the USA President in Warsaw on 15 June 2001 demonstrated that the USA administration had already made strategic decisions with regard to the further enlargement of the Alliance. The address focused on the future of Europe and the project of the unification of Europe: "Today, I have come to the centre of Europe to speak of the future of Europe - but Warsaw is closer to Ireland than it is to the Urals. And it is time to put talk of East and West behind us. Yalta did not ratify a natural divide, it divided a living civilisation. $\langle\ldots\rangle$ No more Munichs. No more Yaltas. $\langle\ldots\rangle$ All of Europe's new democracies, from the Baltic to the Black Sea and all that lie between, should have the same chance for security and freedom - and the same chance to join the institutions of Europe - as Europe's old democracies have. $\langle\ldots\rangle$ Next year, NATO's leaders will meet in Prague. The United States will be prepared to make concrete, historic decisions with its allies to advance NATO enlargement". ${ }^{3}$

Hence, on 15 June 2001, the USA determined to embrace a large-scale NATO enlargement. This address by the USA President stirred up discussions in Europe too. The scenario of a robust enlargement gradually prevailed in Europe. The French President Jacques Chirac, during his visit to the Baltic States, said very outspokenly he was in favour of inviting Lithuania, Latvia and Estonia to join NATO; positive developments were also taking place in the German Bundestag. Traditionally, we received a strong support from Denmark and the new NATO entrants - Poland, the

\footnotetext{
3 "No more Munichs. No more Yaltas - lift up your hearts" - Remarks by the President in address
} to faculty and students of Warsaw University, June 15, 2001. 
Czech Republic and Hungary. In practical terms, what happened then was a direct echo of the call by Z. Brzezinski in his famous speech at the Bratislava Conference of V-10 premiers on 11 May 2001: "NATO's enlargement shall be neither a "bookkeeping exercise", nor a bureaucratic game "guess who?", nor a political market $<\ldots>$ The time has come to escape from the twilight state".

I believe we can state that the terrorist attacks of September 11, in fact, speeded up the culmination of discussions (with these never gaining the momentum) on whether or not to enlarge NATO. The events consolidated and accelerated positive trends on the issues of NATO enlargement following the address by G. W. Bush in Warsaw. For many it became finally clear that enlargement was essential. From a political level, the discussions reached a highly important technical level assessing the aspirants at their performance of annual membership programmes and reform processes in armed forces and other fields.

In the wake of September 11, Lithuania took a determined approach and demonstrated, in political and practical terms, its solidarity with the USA, adhering to the principle "act as an ally". On the basis of the meetings that I had back then with USA diplomats in Vilnius, Brussels, Washington and elsewhere, I may state that Lithuania was appraised for demonstrating an approach which was far more optimistic in comparison with several other candidates on the prospects of NATO enlargement in the period of the global anti-terrorist campaign. We demonstrated that NATO enlargement had been and would remain on the agenda of the USA administration, that a new stage of the USA-Russia cooperation in fight against terrorism would not reduce the possibilities of the integration of Lithuania and other Baltic States into the Alliance. Moreover, such thinking was not grounded only on expectations, but was also backed with information, knowledge, a wide-ranging and deep cooperation with diplomats and politicians of the USA and other NATO member states. Further developments showed that the analysis of the situation was also right that the terrorist attacks against the USA should encourage enlargement as a way to secure stability in a wider area as well as practical and real cooperation in fight against terrorism. During that difficult period it was vital not to make a stop (which was not the case), continue our internal preparation for the membership, including maintaining the level of 2 per cent GDP spending on defence funding, take an active position with regard to the anti-terrorist campaign free from any elements of a virtual political show and link it to our NATO agenda.

The NATO foreign affairs ministerial meeting in Reykjavik on 14-15 May 2002 continued with positive trends of enlargement. The adopted NATO Reykjavik Communiqué stood out for its definiteness reflecting not only the political will of the allies, but, most importantly, concrete modalities of enlargement. Paragraph 6 of the Communiqué reads: "At their Prague Summit in November this year, our Heads of State and Government will launch the next round of NATO enlargement. This will confirm the Alliance's commitment to remain open to new members, and enhance security in the Euro-Atlantic area." ${ }^{4}$ In Reykjavik it was decided that the aspirant countries invited to join the Alliance in Prague would join the Alliance all at the same time prior to next NATO Summit. The Communiqué also reads that the accession

\footnotetext{
${ }^{4}$ Final Communique. Ministerial Meeting of the North Atlantic Council, Reykjavik, 14th of May 2002 .
} 
protocols of the invitees shall be signed not later than in the spring of 2003. It was also agreed to continue the implementation of Membership Action Plans and to use them to facilitate the integration of the invitees into NATO structures. The political will of NATO member states was also illustrated by the fact that in Reykjavik no additional requirements were established which the aspiring countries should have to fulfil, which we feared a little. The MAP was approved; Partnership Goals and other documents formulated the implementation of the objectives before and after the Prague Summit.

\section{Russia's impact on the process of NATO enlargement}

We have to admit straight away that Russia's impact was immense throughout the whole process of NATO enlargement, which is logical given that Russia has always been and will remain a "heavyweight" geopolitical player. Although Russia has never enjoyed nor will ever enjoy the right to veto decisions on NATO enlargement, its direct influence could always be felt - during numerous international conferences, consultations and negotiations there would always be an issue on what had to be done to make Russia feel comfortable during NATO enlargement and help it "save its face". The period between the first wave of enlargement in 1999 and the second one in the middle of 2001 was extremely difficult. In talks with NATO member states, Russia adopted the "cold war" approach underlining categorically its emphatic "no" to NATO enlargement encompassing the Baltic States. In his speech in Bratislava on 11 May 2001 the Czech President Vaclav Havel very precisely pointed out the reasons behind such behaviour of Russia: "The first lies in the inert mode of thinking which persists from the Soviet era when NATO was for decades portrayed by the totalitarian regime and its media as the Soviet Union's arch-enemy. To a certain extent, this was valid: Although NATO had no aggressive intentions, and was not even willing to help those European countries under Soviet domination against whom their alleged Soviet ally perfidiously launched military invasions, it made no secret of the fact that it was designed to contain Communism and that the Soviet Union was its strategic adversary. Nowadays, the situation is completely different, both the Soviet Union and the Warsaw Pact are gone, NATO now pursues other objectives than it did during the Cold War era and desires to be a partner with Russia - but it appears as if Russia has failed to understand or, in fact, to notice this. Time will hopefully change that, at least if the new ruling forces in Russia opt for reality rather than for populism". ${ }^{5}$ A second reason, much more cogent than the first one, according to Mr. V. Havel, was the problem of Russia's identity. "It seems to me that Russia - despite the remarkable progress it has made towards democracy and market economy - is somehow still grappling with a problem with which, to my knowledge, it has grappled for more or less its entire history, that is, with the question of where it begins and where it ends; what belongs to its domain and what is already beyond it $<\ldots>$ Lack of a natural self-confidence of an entity that is sure of its identity, and thus also of its boundaries, seems to be replaced by a slightly imperialistic rhetoric accom-

\footnotetext{
${ }^{5}$ Address by Vaclav Havel, President of the Czech Republic at the Conference "Europe's New
} Democracies: Leadership and Responsibility”, Bratislava, 11th of May, 2001 
panied by a national bombast, which we know so well from people like Mr. V. Zirinovsky, but which appears in Russia in a more cultured form on a much wider scale. For example, I find it almost absurd that such a large and powerful country should be alarmed by the prospect of three small democratic republics at its borders joining a regional grouping (NATO - G.Č.) which it does not control; or, that it should feel a need to build around itself an additional cordon sanitaire - at a time when hundreds of transcontinental missiles could destroy Moscow from Nevada, or New York from the Urals, in a matter of minutes". 6

Today Prague has gone down into history. The second wave of enlargement has already taken place. Bearing in mind that the above speech by Mr. V. Havel was made only a year and a half ago, a conclusion may be drawn that over a very short period of time Russia's position has undergone a remarkable evolution from an open confrontation to a relatively calm resignation with NATO enlargement. I will try to review possible causes for that.

Firstly, it is a strong and consistent support of the USA and other NATO member states to the "open-door" policy. During the NATO Washington Summit on 23-24 April 1999 which concluded the first wave of NATO enlargement, NATO member states confirmed their resolve to continue the "open-door" policy, i.e. to accept new European democracies which, in addition to a strong wish to join NATO, met NATO membership criteria. Indeed, there were various misgivings that we would have to queue at NATO's doors until we catch cold in a draught... Thanks God, this did not happen. NATO states demonstrated the reliability of the "open-door" policy and loyalty to the idea of a free and unanimous Europe. Such position of NATO facilitated understanding among Russian politicians that their policy of an emphatic "no" to NATO enlargement would bear no fruit and that enlargement would happen anyway. An extremely categorical tone of Russia with regard to the membership of Lithuania, Latvia and Estonia of the Alliance as often as not would boomerang against Russia. It would only reinforce our arguments that the Baltic Sates could not stay in "the grey zone", since sooner or later this grey zone would eventually become a tension spot in Europe.

Secondly, the reason for the evolutionary change in Russia's position was related to the first one. Russian diplomacy became aware that by bitterly opposing NATO enlargement they would not win anything. Hence, strict anti-NATO rhetoric was set on a milder tone (though it has never been abandoned altogether) and talks were started on the possibilities of deepening and widening the NATO-Russia cooperation. As early as in March 2001, at a meeting during the official visit of the Lithuanian President V. Adamkus to Moscow, the Russian President V. Putin noted that Lithuania's membership of the Alliance was Lithuania's concern alone. On 3 September of the same year, during his visit to Finland, at a press conference V. Putin thus replied to a question about Russia's view on the membership of the Baltic States in NATO: "It is up to the Baltic States alone to make decisions on their security policy and Russia does not intend to burst into hysteria on account of this" " . This illustrates that the tendency of a tempering hostility of Russia to NATO enlargement started much earlier than the 11 September 2001 terrorist attacks in the USA which became a powerful stimulus to place the plans of developing the NATO-Russia cooperation from a theoretical to a practical dimension.

\footnotetext{
6 ibid.

${ }^{7}$ Reuters, John Acher, 03.09.2001.
} 
A special mention should to be made of the fact that the evolution of Russia's position was also affected by internal democratic processes inside Russia. A "milder" tone with regard to NATO enlargement allowed V. Putin to win a more solid place (and voice) for Russia in the West, while at home it helped to reconcile the public opinion with decisions which Russia could not change, i.e. NATO enlargement.

The establishment of the NATO-Russia Council on 28 May 2002 became a child of a "deeper" cooperation between the West and Russia. The statement of the establishment of the NRC opens as follows: "Today, we have launched a new era in NATO-Russia cooperation". ${ }^{8}$ The Rome statement "NATO-Russia Relations: A New Quality" reads that the Council will work adhering to the principle of a consensus, i.e. not according to the formula "19+1", but " 20 ". This is a clear attempt to disperse an obsolete "block-like" atmosphere that prevailed in the former NATO-Russia Permanent Joint Council. Today, during NRC meetings, the Russian Ambassador does not sit in front of the ambassadors of NATO member states, but according to the alphabetical order of the English language - between Portugal and Spain. The NRC has a wide scope of activities covering fight against terrorism, crisis management, issues of non-proliferation of weapons of mass destruction, measures of weapons control and trust, "theatre missile defence", search and rescue operations at sea, etc. In its statement, the Lithuanian Ministry of Foreign Affairs welcomed the establishment of the NRC since it was indeed in line with foreign policy objectives of Lithuania-by being part of the West, to develop good neighbourly relations with our neighbours in the East. Lithuania hopes that the work of the NRC will bring about tangible results. As a fullyfledged member of NATO, Lithuania will make its contribution to the work of the NRC, availing of its long-standing experience and ideas.

Hence, we may state that Russia, not having a direct impact on decisions of NATO enlargement, yet played a significant role affecting the political mood and even the speed of enlargement. Time will show what the true intentions were behind Russia's tempered criticism of NATO's eastern enlargement and a more pro-Western policy approach. Will the NATO-Russia Council be used as a tool to destroy or dilute the essence of NATO as a most efficient and powerful security organisation in the Western world, will Russia finally feel as an equal partner in the Western cooperation, will the NRC become quite a good stimulator for promoting and instilling Western values and a European inter-state cooperation model in Russia?

\section{Lithuania's policy of building security and trust and Russia}

In the context of cooperation with Russia, Lithuania's security policy pursued after the restoration of independence may be described, without much modesty, as a significant and positive factor that made a major contribution to the creation of Lithuania's image as a serious and solid future partner in NATO. Lithuania's security policy has always been very clear, transparent, polite, resolute and consistent. Since 1994, when the then Lithuanian President A. Brazauskas sent a letter to NATO Secretary General Manfred Woerner requesting to accept Lithuania to the ranks of the North Alliance, it took a lot of patient work to prove a relatively obvious truth that

\footnotetext{
${ }^{8}$ NATO Statements, Rome Summit, 28.05.2002

${ }_{9}^{9}$ Ibid.
} 
Lithuania's membership of NATO did not pose any threat to Russia, that NATO, as well as the European Union, secure our fully-fledged and equal participation in Euro-Atlantic and European processes. On this occasion I frequently recall a view voiced in one of the British dailies that the Baltic States could not pose any threat to Russia even if they wished... Various ostensible bugbears and fears marked the path of Euro-Atlantic integration not only in Russia, but also in the Western world; a degree of concern still remains, which maintains the promotion of security and trust in Europe and the Baltic Sea region as a prioritised area of Lithuania's foreign policy.

The interest in security and stability manifests itself firstly in an active participation in multilateral initiatives and structures consolidating openness, predictability and mutual trust in the military field. As one of such structures, the Organisation for Security and Cooperation in Europe (OSCE) may be mentioned, which over several decades has built a substantial institutional set-up for promoting security and trust and in whose activities Lithuania is actively participating. In this context, the socalled Vienna Document on measures building confidence and security should be mentioned, whose latest amendments were introduced in 1999. The Vienna Document revived and improved trust building measures by means of foreseeing a mandatory exchange of information in the military field, in defence planning, during military exercises and operations, as well as possibilities for regional initiatives. While consistently discharging commitments assumed under this document, Lithuanian institutions submit the required information to other participating states in the OSCE on a regular annual basis and also receive and carry out site visits to military units and regional inspections.

Another important component promoting security and confidence in Lithuania is the Treaty on Open Skies. This Treaty regulates the procedure for monitoring flights of aircraft belonging to the states, parties of this Treaty, above the territories of other participating states. Although the Treaty was signed as early as in 1992, it entered into force only as from 1 January 2002, when Russia and Belarus deposited ratification letters. In May 2002, Lithuania submitted an official application for the membership of this Treaty, which was approved by the Open Skies consultancy commission on 22 July 2002. Following ratification in the Seimas of Lithuania, the Treaty will become effective for Lithuania after 60 days following the deposit of the ratification letters. There is no doubt that Lithuania's participation in this Treaty will further contribute to building openness and mutual confidence between neighbouring countries in the military area.

Moreover, Lithuania expects that the conditions necessary to adapt an agreement for the ratification of the CFE Treaty will be fulfilled, and this Treaty will be made open for new members. In his speech at the United Nations General Assembly on 12 August 2002, President V. Adamkus stated clearly that Lithuania would seek to accede to the CFE Treaty.

Apart from participation in multilateral initiatives, for the past decade Lithuania has been actively involved in developing additional bilateral confidence and security building measures (CSBMs) with neighbouring states. These measures are mostly based on the provisions of the said OSCE Vienna Document and the Treaty on Conventional Forces in Europe. The official start of the policy of bilateral confidence and security building measures may be deemed to be a statement by the President of the Republic of Lithuania Valdas Adamkus on 26 March 1998. In order to further 
build an atmosphere of openness and mutual confidence, the statement proposed that the neighbouring states apply additional measures of openness, such as notification about major military exercises, exchange of additional inspections and military data verification visits. Inspired by this statement, we addressed Russia proposing to agree on additional inspection visits, exchange of military information and early warning about major military exercises. The negotiations at the beginning of 2001 resulted in a successful agreement on an additional military data verification visit per year, on the basis of which Lithuania was entitled to perform checks of Russia's military units in Kaliningrad region. In addition, we also agreed to exchange, on an annual basis, additional information about armed forces present in Lithuania and Kaliningrad region, under the provisions of the Treaty on Conventional Forces in Europe. In March 2001, during an official visit of President V. Adamkus to Moscow, Presidents of Lithuania and Russia welcomed agreements on bilateral security and confidence building measures, noting that Lithuania and Russia were planning to initiate further joint actions in this field as well as enter into bilateral contacts between military services of both countries.

It is gratifying to note that the earlier mentioned agreements with Russia did not remain only intentions on paper, but are being put into practice. Last July, Lithuania carried out a data verification visit to Kaliningrad region, an exchange of information under the CFE Treaty took place at the beginning of 2002. On 10 April 2001, 10 Russian military officers took part in military environment courses in the Nemenčinè Refresher Training Centre for Servicemen (with the help of the USA and Sweden). In June 2001, Lithuania's Ministry of National Defence and the USA Defence Department organised in Lithuania a seminar - military exercises entitled "CivilMilitary Emergency Planning 2001". The seminar was attended by a group of Russian delegates. Since 1997, Lithuania has been inviting military observers from Russia to key military exercises of a calendar year in its territory. A number of visits by senior officers of the Defence Ministry and Armed Forces commanders have been organised: a visit by V. Valuyev, the Baltic Fleet Commander, the Vice-Admiral of the Russian Federation, in September 2001, two visits by the Lithuanian Minister of National Defence L. Linkevičius in 2002 to meet the Russian Defence Minister S. Ivanov. In September 2002, Klaipeda was paid the first visit by the warships of the Russian Federation - minesweepers "A. Lebedev" and BT 212. In addition to the warships, the military orchestra of the Baltic Fleet of the Russian Federation also paid a visit. Prior to the visit, Lithuanian Days were organised in Kaliningrad were Lithuania was represented by the military orchestra and the basketball team of the Motorised Infantry Brigade "Geležinis Vilkas" of the Ministry of National Defence.

Intentionally, wishing to underline their importance, did I mention these military to military events. I recall a meeting with Vice-Admiral V. Valuyev, who back then, in the autumn of 2001, paid his first visit to Lithuania. When sharing his impressions about Vilnius, the Vice-Admiral expressed his amazement that when they, i.e. a group of Russian officers, dressed up in uniforms, were walking in the city nobody (!) abused them verbally or threw stones at them... Indeed, a better understanding of each other helps to dispel still prevalent myths or outright lies of the old Soviet propaganda. The Vice-Admiral concluded the reception hosted on the occasion of the visit with the following toast: "NATO is not a stumbling block to friendship". 
It should be noted that the feature of Lithuania's security policy to be modern, contemporary and to react rapidly to the nuances of the development of the geopolitical situation depended on the improvements of the regulatory framework. In 20012002, the National Security Strategy was drafted which was adopted by the Seimas of the Republic of Lithuania on 28 May 2002. At the beginning of 2002, the Law on International Operations, Military Exercises and Other Military Events of Military Cooperation was amended. The new version of the law reduced the restrictions applicable to defensive cooperation with the CIS. Under the new formula of the law, the authorisation to enter Lithuania for a limited period of time may be granted to CIS military units participating in exercises under the Partnership for Peace (PfP) or other international exercises organised in cooperation with member states of NATO or the European Union. The law provides for a legal basis for the participation of Lithuanian troops in exercises organised under NATO's international cooperation programmes in CIS countries and international operations taking place in their territories. The adoption of the National Security Strategy (NSS) means the beginning of a new phase in quality terms - a transition from the post-Soviet objectives of reconstruction (and a corresponding thinking in security policy) to Lithuania with a different type of functioning - as a modern and mature democracy with a functioning market economy and consistent integration into NATO and the EU - communities cherishing Western values. The NSS states the absence of a direct military threat to Lithuania from abroad, hence, no foreign state is Lithuania's enemy. Within the meaning of the National Security Strategy, international security is seen as indivisible, which is why safeguarding of peace and stability in other regions is seen as a complementary part to building a secure future for Lithuania. Considerable attention in the NSS is attached to "new threats", such as international terrorism, proliferation of weapons of mass destruction, illegal migration, smuggling, drug trafficking, corruption, etc. It is absolutely clear that upon Lithuania's accession to NATO, the composition of priorities of security policy is to change alongside the arsenal of implementation measures. The NSS will, therefore, have to be revised and adapted accordingly to reflect the new period.

Hence, Lithuania's security policy clearly reflects the features of Lithuania's "maturity" as a state, its consistent efforts to implement good neighbourly relations, in particular, with Russia. The indicated aspects contribute to our better presence and appreciation by the international community. More than once have I heard positive responses to Lithuania's policy towards neighbours, whereas bilateral confidence and security building measures with Russia (and Belarus) are presented as a model for the openness in the military field contributing towards security in Europe.

Certainly, there are certain problems in the relations with Russia. We, as Russia's neighbours, can do only part of the job. Just like any other policy, security policy cannot be unilateral. Reciprocity is needed. We hope that such vital and yet "frozen" issues on the Russian side as the ratification of the border treaty and the signing of the readmission treaty, etc. will pick up speed. 


\section{Lithuania's "homework" and NATO}

Though briefly, I would still like to refer to Lithuania's Membership Action Plans and their significance for the integration into NATO. Although the Alliance's decision to enlarge is a political act, we can firmly state that without Lithuania's efforts to implement MAPs a chance of being invited to NATO in Prague would have been minimal. Understanding the political and practical significance of MAPs, Lithuania actively participated in this process from its very start.

During the first wave of NATO enlargement, when Poland, the Czech Republic and Hungary were admitted to the Alliance, there were no membership action plans. However, life has shown that the candidates did not have enough time to prepare for the membership, and the Alliance found itself facing major practical challenges, when integrating, in political and military terms, the new entrants which were invited in 1997 and admitted in 1999. Therefore, the NATO Washington Summit in 1999 proposed candidate countries a pre-accession programme - the Membership Action Plan (MAP). The essence of the MAP process is as follows: through consultations with NATO, the aspiring countries shall define aims and requirements they should fulfil so that their membership of the Alliance would not weaken the organisation or diminish its effectiveness. Such aims are based on the principles laid down in the 1995 NATO Enlargement Study as well as those stipulated in annual national membership action plans. NATO officers and the Alliance's members closely follow the implementation of these aims and submit their appraisals and proposals to the candidates on a regular basis. The structure of the MAP was specially built to cover a full range of criteria of the preparation for the membership. The MAP is made up of five composite sections: political/ economic, defensive, resources, legal and security.

The aim of the MAP's Political/economic section is to secure continuity and irreversibility of democratic reforms, to prove that a candidate country has really instilled the principles of freedom and democracy in their society (democratic elections; the rule of law; respect for human rights; civil control of the army; freedom of the media; protection of ethnic minorities and their integration into society; fight against corruption and terrorism, etc.), that the aspiration of membership is based on a realistic consensus of political forces and societal consent, that a candidate has a functioning market economy which will allow making a contribution to the Alliance rather than building security at the expense of other members of NATO. The aim of the MAP's Defence section is to establish such direction for the development of national armed forces which would allow for an effective organisation of defence of the home country by means of accepting assistance from the allies, to provide such assistance to other allies (the famous principle of NATO "all for one and one for all") and to contribute to non-Article 5 missions undertaken by NATO, such as peacekeeping, humanitarian aid, etc. On the basis of this particular section of the MAP, Lithuania initiated and, drawing on the resources of its own and NATO member states, is effectively implementing its defence reform, whose aims and composition have been coordinated with the Alliance. The purpose of the Resources section is to secure that defence development plans, coordinated with the Alliance, should have really available sums of money, whereas the purpose of the Legal section is to abolish any legal hindrances for Lithuania's accession to the Washington Treaty and dischar- 
ge the commitments enshrined in this Treaty. The key objective of the section on Security is to ensure that upon membership of NATO, Lithuania should be able to credibly protect extensive flows of classified information, or, in other words, should credibly guard secrets confided to it by the Alliance. To this end, Lithuania has introduced procedures for the verification of credibility of individuals dealing with classified information, took protective measures in line with the Alliance's standards on physical protection of information, introduced protective procedures and measures applied in NATO with regard to information transmitted by wire, radio and electronic means.

Even a very short description of the sections illustrates how politically significant for Lithuania and for its image in the eyes of future NATO partners was the successful implementation of the MAP (alongside the adoption of the EU acquis), which was of seemingly "technical nature". The MAP process allowed for timesaving, "not reinventing the wheel". The MAP contributed to the promotion of reforms inside Lithuania even in the fields other than the military. Therefore, it was useful both to us (even if we had not received an invitation in Prague) and NATO. I would dare say that the successful implementation of MAPs in Lithuania and other Baltic States encouraged the political will of NATO member states for the enlargement into the Baltic States and ensured the invitation to membership in Prague.

\section{After Prague: what is next? "A golden province of Europe"}

After the Prague Summit, a question that arises naturally is what will happen next? While attempting to answer this question, it is necessary to talk about short-term and medium-term objectives, i.e. about the period from the invitation in Prague to the "true" membership of Lithuania in NATO in 2004 and the post-membership period.

The key motto of the post-Prague period should be "not to relax, not to rest on the laurels". The invitation does not yet mean membership; right are those politicians and diplomats who state that all work is yet ahead. It is, therefore, self-evident that Lithuania's security policy agenda will be dominated by the tasks related to the successful completion of the strategic aim of NATO membership. Firstly, this implies attention to ratification processes in NATO member states as well as at home, continued cooperation within the V-10 group, further implementation of the Membership Action Plan. Particular attention must be devoted to the implementation of the Lithuanian defence reform and maintaining financial commitments. Lithuania, as before, will carry on its active participation in international military exercises in various formats: in joint projects of the Baltic States, in cooperation with Danish and Polish forces, etc. It is necessary to continue an active participation in the regimes of arms control and confidence building measures (the OSCE Vienna Document, bilateral security and confidence building measures with Russia and Belarus, conventions on non-proliferation of weapons of mass destruction, regimes and cooperation agreements). There are many objectives important from the "technical" point of view, such as the extension of the Lithuanian mission at NATO in Brussels, reconstruction of corresponding structures in Vilnius - the Ministry of Foreign Affairs and the Ministry of National Defence, - issues of human resources, refresher training, etc. 
In 2004, Lithuania will become a fully-fledged member of NATO and the European Union. This will substantially change the quality of Lithuania's security policy. Two out of three key objectives of Lithuanian foreign policy (membership of NATO, membership of the EU and good neighbourly relations) will have been implemented. Shall we, having completed these strategic for the existence of the Lithuanian state projects, not lose the sense of direction, will we be able to adapt politically, psychologically and institutionally? Clearly, many previous provisions of security policy and working methods will have to be revised and redefined. It is likely that such review will take place in the form of a new version of the National Security Strategy or, maybe, by amending the Law on the Fundamentals of National Security. It will be possible to keep the sense of direction by realising the key issues of Lithuania's concern. Even after the membership of NATO and the EU, many efforts will be needed trying to "catch-up" with the states of the Western world and later to maintain Lithuania in the community of Western states as a fully-fledged member. I would, therefore, think that Lithuania's foreign policy will need new projects and ideas that would allow to reinforce, in quality terms, Lithuania's cooperation with its "new families", i.e. NATO and EU member states (with the West!). This may become a serious challenge, because this work is not as apparent on the surface, revolutionary or expressive as the slogans in favour of the unification of Europe. This calls for many more administrative capacities (resourcefulness) that are difficult to build and do not make newspaper headlines. In other words, there will be the need to learn to work according to the Western routine in a good sense. Lithuania's activities in various international forums (V-10, NB8 security policy dimension, $5+3+1$, the USA-Baltic States Charter, etc.) will inevitably have to be reviewed through NATO's and the EU's perspective. The membership of these organisations will open additional opportunities for Lithuanian diplomacy in the fields of economy, energy and ecology.

We will not miss the direction provided we continue adhering to the principle that the basis for the security in Europe is a strong transatlantic link. The transatlantic link is a guarantee of the future of NATO as a defence alliance. Hence, alongside all other members of the Western community, we will have to cherish this link as well as see to it that it is not ousted by old local ambitions, so well-known from the books of history, disguised as "new" ideas of the security architecture...

December 2002 